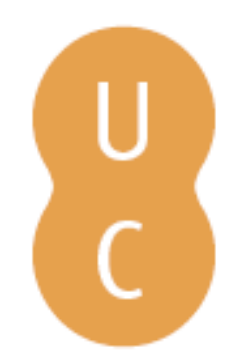

\title{
nommalina
}

\section{Ethos e Praxis na Poética Aristotélica}

Autor(es): $\quad$ Soares, Martinho

Publicado por: Imprensa da Universidade de Coimbra

URL

persistente: URI:http://hdl.handle.net/10316.2/43576

DOI: $\quad$ DOl:https://doi.org/10.14195/978-989-26-1380-2_3

Accessed : $\quad$ 26-Apr-2023 11:03:02

A navegação consulta e descarregamento dos títulos inseridos nas Bibliotecas Digitais UC Digitalis, UC Pombalina e UC Impactum, pressupõem a aceitação plena e sem reservas dos Termos e Condições de Uso destas Bibliotecas Digitais, disponíveis em https://digitalis.uc.pt/pt-pt/termos.

Conforme exposto nos referidos Termos e Condições de Uso, o descarregamento de títulos de acesso restrito requer uma licença válida de autorização devendo o utilizador aceder ao(s) documento(s) a partir de um endereço de IP da instituição detentora da supramencionada licença.

Ao utilizador é apenas permitido o descarregamento para uso pessoal, pelo que o emprego do(s) título(s) descarregado(s) para outro fim, designadamente comercial, carece de autorização do respetivo autor ou editor da obra.

Na medida em que todas as obras da UC Digitalis se encontram protegidas pelo Código do Direito de Autor e Direitos Conexos e demais legislação aplicável, toda a cópia, parcial ou total, deste documento, nos casos em que é legalmente admitida, deverá conter ou fazer-se acompanhar por este aviso.

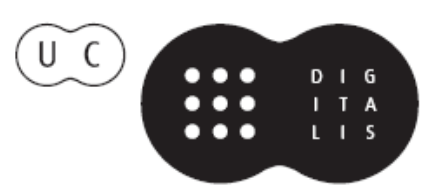




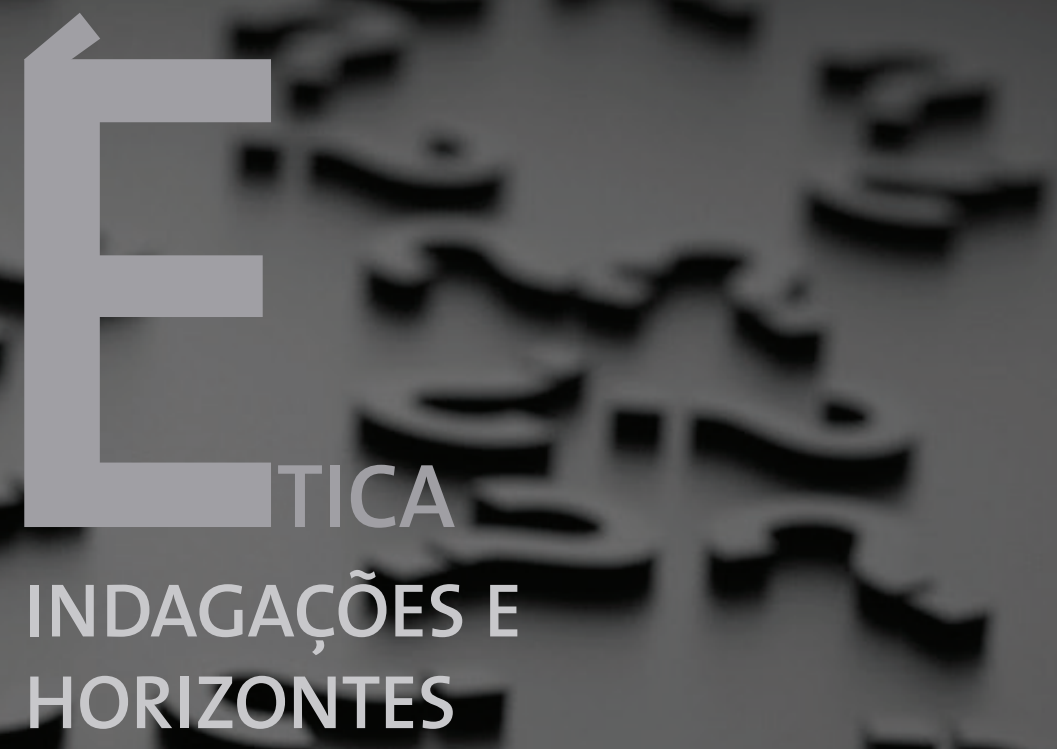

Maria Formosinho Paulo Jesus Carlos Reis (Coord.)
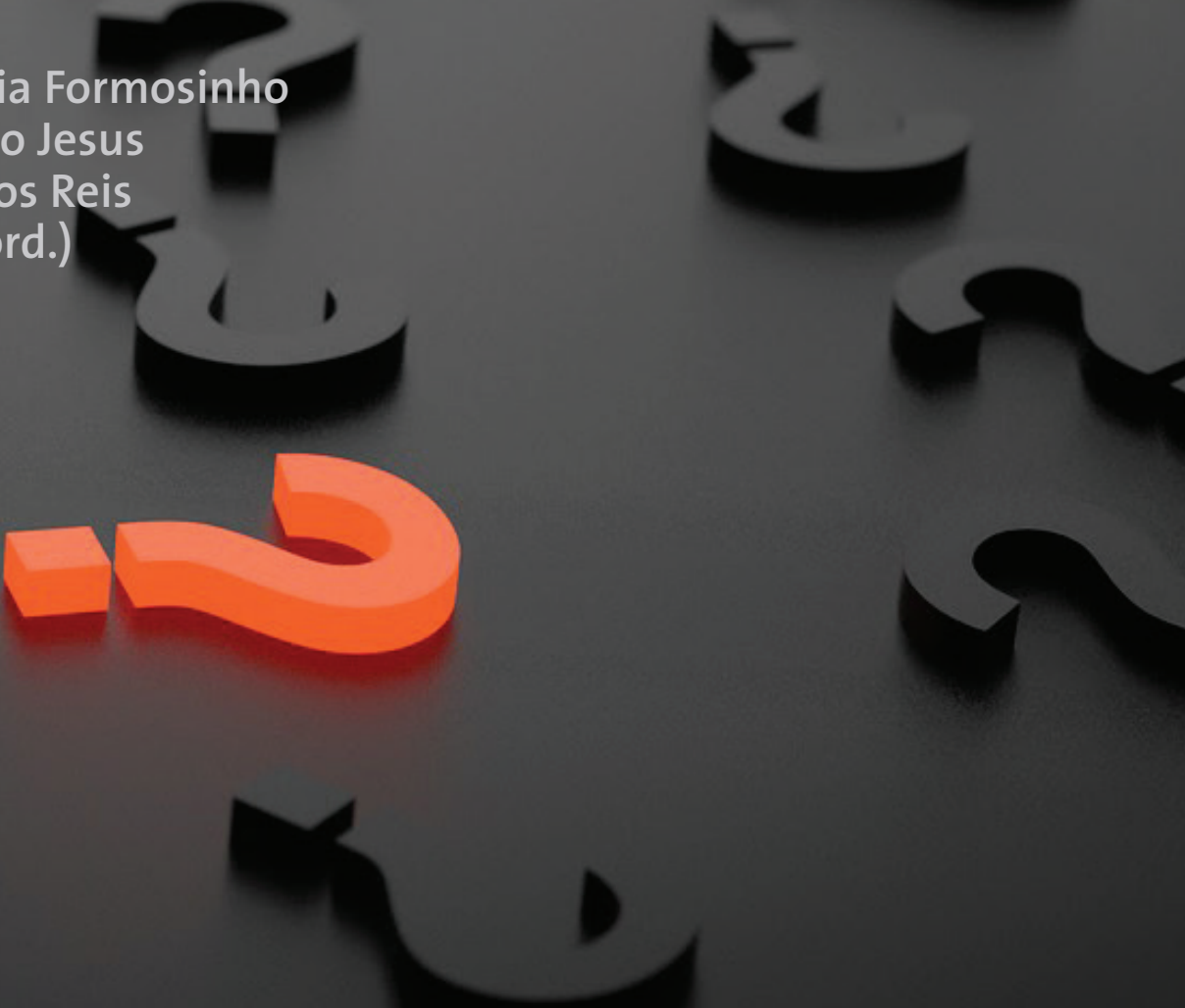


\title{
CAPÍTULO III
}

\section{ETHOS E PRAXIS NA POÉTICA ARISTOTÉLICA}

\author{
Martinho Soares ${ }^{1}$
}

\section{Introdução}

Na raiz semântica do conceito de Ética está o étimo grego êthos. Este tanto pode designar "carácter" e "personagem", como "costume" e, no plural, "morada”. A ideia fundadora e fundamental do conceito, que lhe permite assegurar a coesão lexical entre os vários referentes, é a de permanência, hábito, durabilidade. Assim se compreende que ele tanto possa referir a morada, enquanto lugar de permanência; a identidade ou o carácter de um indivíduo, como disposição estável, e, por conseguinte, de uma personagem (que mais não é do que a efabulação de um indivíduo); ou a de um povo, com todos os seus costumes e valores sociais sedimentados. Na perspetiva aristotélica, que é prioritariamente a exposta na Ética a Nicómaco, a ética diz respeito ao indivíduo agente e à forma como este há-de conduzir a sua ação para a felicidade e a vida boa. Nesse âmbito surge um conjunto de conceitos chave para a enteléquia humana: heixis, traduzido por "disposição adquirida", é um constituinte fundamental do carácter e conceito antropológico de base da Ética aristotélica; phronesis, com o sentido de "sensatez" e "sabedoria prática", define o homem que sabe conduzir as suas açóes para a felicidade e para a vida boa, através da eleição da virtude. Esta, designada arête, exprime a "excelência" que deve orientar toda a praxis humana. Outros conceitos fundamentais como praxis, telos, ergon, hedonê, eudaimonia, philia, dikaiosunê jogam em função de uma conceção eminentemente subjetiva e individualista de ética que os escritos aristotélicos sobre Política posteriormente virão abrir ao mais amplo campo comunitário, social. Na Poética, a dimensão da poiesis sobrepóe-se à dimensão ética, na razão da sobreposição da ação (praxis) sobre o agente (êthos). Todavia, a dialética praxis/êthos, geradora de Poética e de Ética, abre-nos caminho para desveladas consideraçóes (po)éticas que aqui queremos expor.

\footnotetext{
${ }^{1}$ Centro de Estudos Clássicos e Humanísticos da Universidade de Coimbra.
} 


\section{A Poética como laboratório da Ética}

A Poética reflete sobre o importante mundo dos textos dramáticos e épicos da literatura grega, os quais são, inquestionavelmente, autênticos laboratórios do imaginário, lugar de fundadoras experiências de teor ético, que geram no leitor ou no espectador juízos de valor e de avaliação ética.

O tratado literário aristotélico insere-se numa tradição que tem em Platão a grande fonte de onde emanam muitos dos conceitos ético-poético-políticos que enformam o pensamento do Estagirita. Embora Aristóteles se distancie do seu mestre quando advoga que os critérios para julgar a poesia não se confundem com preceitos ético-políticos de moral, verdade ou realidade, como preconizava Platão — bem pelo contrário, a poesia deve medir-se com critérios exclusivamente poéticos aproxima-se do Académico ao esperar que a tragédia exerça uma função moralizante sobre os espectadores; daí a prescrição de que não se devem representar indivíduos moralmente desprezíveis passando do infortúnio à felicidade nem vice-versa, porque este facto, em vez de provocar temor e compaixão, suscita repugnância. ${ }^{2}$

Esta dissonância entre mestre e discípulo não é de monta a anular a realidade das ideias e a realidade dos valores éticos como os dois pilares fundamentais da filosofia e da metafísica platónico-aristotélica. Ao considerar que há valores morais e cognitivos implícitos na obra poética, Aristóteles é essencialmente platónico; isso náo o impede, porém, de se afastar do seu antecessor, ao atenuar a rigidez moral e cognitiva do conceito de mimesis: o imitado ou a poesia deixa de ser indigna do filósofo ou do cidadão virtuoso, visto que a poesia não é mimesis de matérias contingentes, mutáveis e enganosas, mas de formas universais tal como são ou poderiam ser em virtude do verosímil e do necessário. Assim, a imitação não pode ser prejudicial nem para a busca da verdade nem para o desejo de retidão moral que caracterizam o filósofo.

A intriga não só imita universais como é ela mesma um feito universal. Tal poder advém-lhe da composição ordenada e harmoniosa que lhe confere totalidade e coesão. A universalidade da intriga acontece se a estrutura do mythos repousa no nexo causal interno da ação e não em acidentes externos ou episódicos. A conexão interna da intriga gera universais, os quais não são ideias platónicas, mas parentes da sabedoria prática e, logo, da ética e da política (cf. Ricoeur, 1983, p. 85). Assim, "compor uma intriga é já fazer surgir o inteligível do acidental, o universal do singular, o necessário ou o verosímil do episódico" (Ricoeur, 1983, p. 85). É Aristóteles quem o diz:

2 “[...] é evidente, em primeiro lugar, que se não devem representar os homens bons a passar da felicidade para a infelicidade, pois tal mudança suscita repulsa, mas não temor nem piedade; nem os maus a passar da infelicidade para a felicidade, porque uma tal situação é de todas a mais contrária ao trágico, visto não conter nenhum dos requisitos devidos, e não provocar benevolência, compaixáo ou temor; nem táo pouco os muito perversos a resvalar da fortuna para a desgraça" (Aristóteles, 2004, 1452b 34-38). 
[...] o poeta deve ser um construtor de enredos mais do que de versos, uma vez que é poeta devido à imitação e imita acçóes. E, se lhe acontece escrever sobre factos reais, não é menos poeta por isso: nada impede que alguns factos que realmente aconteceram sejam [possíveis e] verosímeis e é nessa medida que ele é o seu poeta (2004, 1451b 28-32).

O poeta é, deste modo, considerado o construtor de intrigas e o imitador de açóes (praxeis), ofício que lhe é outorgado pela própria semântica do vocábulo "poeta", cognato do verbo poiein, que significa, justamente, "fazer", "fabricar", "construir"3. Neste sentido, pode dizer-se que a tragédia é um "fazer" sobre um "fazer". Simplesmente, o fazer mimético não é efetivo ou ético, é inventado ou poético. É que

no interior da mimesis desenvolve-se uma tensão entre a submissão à realidade da acção humana e o trabalho criador, que é a poesia em si mesma, porque o real da referência mimética não é algo cristalizado e inerte, de que só seria possível uma cópia, mas o reino da natureza enquanto fonte dinâmica e criadora, de que só há mimesis quando também se cria. Por isso toda a poesis é mimética e toda a mimesis é poética. (Baptista Pereira, 1993, p.428)

Assim, "ela mantém simultaneamente uma proximidade com a realidade e a distância efabuladora, que permite magnificar as acçôes imitadas" (Portocarrero, 2005, p. 64).

Toda a mimesis é mimesis praxeos e todo o mythos é sunthesis pragmatôn, e isto implica que só há catarse se houver efabulação de ações, ou seja, a mimese consiste na representação imitativa de açôes que a intriga reúne e combina de forma coerente e consequente, de modo a produzir reconhecimento e prazer no espectador. A ação — não o herói — é a responsável pela unidade da obra poética, e a unidade da ação é o alicerce de qualquer arte mimética, seja tragédia ou epopeia.

\footnotetext{
${ }^{3}$ Aristóteles aproxima, em estreita conexão, os dois momentos fulcrais da composição poética, mythos e mimesis, sendo a açáo humana (praxis) o seu grande unificador. Estes dois termos, no Estagirita, trazem em si a marca dinâmica de produção, construçấo, que lhes advém do verbo poiein, que significa fazer, construir, elaborar, e que, por sua vez, dá origem ao adjetivo "poética", de "arte poética". A poiesis é uma arte (techne), é uma técnica de composição, um ofício como o do carpinteiro ou do tecelão, logo, mythos e mimesis têm de ser entendidos como operaçóes e não como estruturas. Mythos não é apenas sistema, mas agenciamento dos factos em sistema (1450a 5) ou composição de uma intriga, e mimesis é a atividade ou processo ativo e criador de imitar ou representar, através da articulação discursivo-narrativa, os homens em ação. Por outras palavras, podemos dizer que o mythos aristotélico é intriga, argumento, narrativa ou "estória" - diferente de "história", no sentido de historiografia - e mimesis é representação ou imitação, mas não no sentido de cópia passiva ou réplica. Aliás, é de remarcar que, em grego, as palavras terminadas pelo sufixo -sis, como poiesis, sustasis, mimesis, são substantivos abstratos com o traço semântico de "processo", "ação", "dinamismo".
} 
De facto, na vida de um só indivíduo podem produzir-se imensos acontecimentos que não formam uma unidade entre si. Ao contrário, a unidade da intriga trágica está relacionada com a formação de uma totalidade organizada, pois todos os acontecimentos que a constituem estâo ordenados de acordo com o verosímil e o necessário, de molde a criar uma obra bela.

Sublinhe-se que, apesar de tudo, Aristóteles não desqualifica as personagens, apenas as coloca em segundo plano na hierarquia da narrativa. Recorde-se que, também na narrativa semiótica contemporânea, Vladimir Propp sobrepóe às próprias personagens as "funçôes" que estas desempenham na intriga.

A tragédia, ao imitar uma ação, imita, através dela, também os indivíduos que agem: "A tragédia é a imitação de uma ação e, através desta, principalmente dos homens que atuam" (Aristóteles, 2004, 1450b 34) — ideia que Aristóteles náo se cansa de vincar:

De facto, toda a tragédia é [antes de mais] a imitação de uma acção [mimesis praxeos] e uma acção é levada a cabo por indivíduos que agem, que necessariamente têm de ser de uma maneira ou de outra, segundo o seu carácter e pensamento [kata te to êthos kai tên dianoian]. (1449b 34-37) ${ }^{4}$

\section{E, logo a seguir:}

Como a tragédia é a imitação de uma acção e é realizada pela actuação de algumas pessoas que, necessariamente, são diferentes no carácter e no pensamento (é através disto que classificamos as acçôes [são duas as causas das açôes: o pensamento e o carácter] e é por causa destas acções que todos vencem ou fracassam), o enredo é a imitação da acção, entendendo aqui por enredo a estruturaçáo dos acontecimentos, enquanto os caracteres são o que nos permite dizer que as pessoas que agem têm certas qualidades [...]. (1449b 36; 1450a 8)

Todavia, se por um lado a ação depende da qualidade dos seus caracteres ou da sua maneira de ser e dos seus pensamentos, por outro, estes elementos estão-lhe subordinados, pois que ela é forçosamente o objeto principal da mimese:

Mas o mais importante de todos é a estruturação dos acontecimentos. É que a tragédia não é a imitação [mimesis] dos homens, mas das acções e da vida [...] Aliás, eles [os personagens (mimêsôntai)] não actuam para imitar os caracteres [ ta êthể], mas os caracteres é que são abrangidos pelas acçóes [praxeis]. Assim, os acontecimentos [ta pragmata] e o enredo [mythos] são o objectivo

${ }^{4}$ A tradução é da nossa responsabilidade, por se pretender uma tradução mais literal do texto aristotélico. 
[teleos] da tragédia e o objetivo é o mais importante de tudo. Além disso, não haveria tragédia sem acção, mas poderia haver sem caracteres (1450a 1624).

Não restam, pois, dúvidas de que a praxis — intrínseca e mutuamente implicada no mythos - é "a parte principal, o objeto visado, o princípio e, talvez possamos dizer, a alma da tragédia” (Ricoeur, 1983, p. 71).

Ao passo que na Ética a Nicómaco (2001, II, 1105a 30 seq.), o filósofo grego dá primazia ao sujeito sobre a açáo, na Poética, é a tessitura da intriga (consoante seja epopeia, tragédia ou comédia) que comanda claramente a qualidade ética dos caracteres. De fato, a diferenciação entre os três géneros poéticos não é feita com base no cânon poético que rege toda a teoria, a saber, o da mimesis praxeos, mas tem que ver com os critérios éticos de nobreza e de baixeza, virtude e vício. A tragédia imita indivíduos melhores que os atuais, isto é, pessoas nobres e virtuosas, e a comédia imita indivíduos piores, de baixa condição. Aristóteles faz, portanto, uma tripla distinção sobre o estatuto do objeto imitado (melhor, pior ou igual) sendo que esta última categoria, homens iguais aos atuais, fica por preencher, por não corresponder ao objeto de nenhum género literário.

Uma vez que quem imita representa os homens em ação, é forçoso que estes sejam bons ou maus (os caracteres quase sempre se distribuem por estas categorias, isto é, todos [pantes] distinguem os caracteres pelo vício e pela virtude) e melhores do que nós ou piores ou tal e qual somos, como fazem os pintores $[. .$.$] também a tragédia se distingue da comédia neste aspecto: esta$ quer representar os homens inferiores, aquela superiores aos da realidade. (Aristóteles, 2004, 1448a 14; 16-18)

Klimis encontra aqui prova suficiente para entender a mimesis no sentido de "estilização" e não de mera reprodução ${ }^{5}$. Na verdade, ao falarmos de mimesis, temos de tomar duas precauçóes relativamente à tradução e significado do conceito: em primeiro lugar, se traduzimos mimesis por imitação, não falamos de um decalque de um real existente, mas antes de uma imitação criativa; em segundo, se traduzimos mimesis por representação, não falamos de duplicação de presença, à guisa da mimesis platónica, mas antes do corte que abre o espaço de ficção. Neste sentido, Ricoeur observa que é o significado aristotélico de mimesis que serve de critério para a instauração do conceito moderno de literariedade de uma obra literária (1983, p. 93).

A dimensão criativa da mimese vem dessa representação de homens melhores ou piores que os existentes, uma vez que dispensa a cópia dos homens como realmente são e preocupa-se, fundamentalmente, em representá-los como pode-

5 «Nous trouvons donc dans ce chapitre la preuve que c'est bien dans le sens d'une 'stylisation' qu'Aristote entend la mimèsis, et certainement pas dans celui d'une simple 'imitation'» (Klimis, 1997, p.113). 
riam ou deveriam ser. Ora, esta asserção, melhores ou piores que os atuais, tem fortes e evidentes contornos éticos e cognitivos; eventualmente morais, quando há quebra da lei. O espectador é convidado a confrontar o seu comportamento com os das personagens em ação e daí retirar juízos sobre a sua própria conduta. Mas para que haja confronto e identificação ética e emocional com as personagens, é fundamental que a intriga cumpra determinados requisitos. Há normas para se obter uma tragédia com qualidade. Elas assentam sobre dois eixos principais: a nobreza e a baixeza de carácter das personagens e o fim afortunado ou desafortunado que elas devem atingir. Assim, não se deve mostrar indivíduos muito nobres passando da sorte à desgraça, pois tal não é terrível e suscitador de compaixão, mas antes repulsivo, nem se deve táo pouco mostrar os malvados a passar da desgraça à ventura, pois isso não é nada trágico, uma vez que náo provoca terror nem compaixáo, para além de náo ser eticamente correto. Uma personagem malvada a passar da dita à desdita também não desperta comiseração e pavor, apenas, talvez, um sentido de justiça. O que se deve representar é alguém da nossa condição, com quem nos possamos assemelhar, alguém que, sem o merecer, sofre um enorme revés que o lança na desgraça. Isso gera nos espectadores verdadeiro assombro e piedade, emoçóes trágicas que regulam a hierarquização destas combinações possíveis. Aristóteles explicita que "a compaixão tem por objeto quem não merece a desdita, e o temor visa os que se assemelham a nós" (1453a 45). Em suma, da composição poética devem ser excluídas quaisquer ações repugnantes, monstruosas ou desumanas, pois é essencial que o herói seja alguém com quem o espectador se possa identificar, de molde a sentir as emoçôes trágicas que são o sucesso das tragédias.

Fica, pois, patente que o herói trágico aristotélico não deve ser excelsamente virtuoso e justo nem demasiado mau ou perverso, a sua queda deve ser justificada não por uma grande maldade, mas simplesmente por uma hamartia, isto é, por um erro fatal pelo qual não é totalmente responsável. A essência do trágico reside exatamente na fragilidade e finitude da condição humana, as quais ocasionam a hamartia ${ }^{6}$. Se o Homem fosse perfeito, anular-se-ia a sua condição e a possibilidade de se gerar um conflito trágico. De igual modo, comenta Fialho:

\footnotetext{
6 A palavra grega hamartia, normalmente traduzida por "erro", é cognata do substantivo abstrato hamartema e do verbo hamartano, que aparece documentado na Ilíada com o sentido de "errar o alvo". Contudo, este vocábulo tem tido várias interpretaçóes ao longo dos séculos, dando azo a profusa literatura. Por motivos óbvios, não vamos aqui fazer uma exposição das suas várias aceçôes. No entanto, para um estudo aprofundado do termo, aconselhamos a consulta da obra de Jan Bremer (1969), Hamartia, totalmente dedicada à multiplicidade semântica do conceito; a tradução da Poética e respetivos comentários da autoria de Lucas (1968); a introdução de Rocha Pereira à tradução da Poética (2004); e o artigo de Fialho (1977), "Algumas consideraçôes sobre o Homem trágico". A partir das várias ocorrências da palavra na Poética, pode verificarse que "hamartia” e "hamartema" podiam ser usados em relaçâo "a qualquer acção cujo resultado falhou", e que podiam "abranger igualmente erro e crime”" (Rocha Pereira, 2004, p. 25). Na Ética a Nicómaco (2001, V 1135b 1625) o Estagirita apresenta três conceitos afins: "hamartema", que significa "erro", no
} 
se a modificação se operasse apenas a nível de ficção dramática, cessaria a possibilidade de comunicação espectador-tragédia, já que entre aquele e as personagens envolvidas nesta (que o deixaria de ser, por sua vez) cessaria a possibilidade de uma linguagem comum, de uma experiência comum (1977, p. 382).

Para que a tragédia possa existir, possa atingir o seu efeito próprio, e produzir prazer intelectual, adveniente do reconhecimento, é fundamental que represente ações de seres finitos e contingentes, presos entre a precariedade e a realizaçáo absoluta. Esta exigência faz da hamartia o "cerne da própria tragédia”, porque "cerne da própria condição humana" (Fialho, 1977, p. 387).

Deste modo, o recetor da tragédia torna-se juiz, não ministro da lei, reconhecendo-se tão falível como o herói atingido pelo infortúnio. ${ }^{7}$ É pela qualidade emocional do temor, da compaixão e do humanismo que o espectador discerne a falta trágica. A sua resposta emocional é construída no próprio drama, através de incidentes destrutivos e dolorosos que afetam as personagens. A katharsis, conceito fundamental na definição de tragédia, designando a purificação ou purgação das emoçóes, é operada pela composição da própria intriga, sendo as emoçóes depuradas as reguladoras do discernimento do trágico. Por isso, refere Aristóteles, no capítulo XIV, que não é necessário que o terror e a compaixão resultem do espetáculo, é preferível - e aí se vê a qualidade do poeta - que essas emoçôes sejam resultado do próprio texto, de forma que alguém que não veja a representação, mas leia ou escute o argumento, se aterrorize e sinta compaixáo, como acontece, por exemplo, no Rei Édipo de Sófocles. Ademais, adverte o filósofo grego no mesmo capítulo:

[...] não se deve procurar na tragédia toda a espécie de prazer, mas a que lhe é peculiar. E, uma vez que o poeta deve suscitar, através da imitação, o

sentido lato; "athychema", falta involuntária; e "adikema", injustiça. Assim, na tragédia, hamartia "é uma certa forma profunda de ignorância que conduz a consequências desastrosas sem subverter a integridade moral do herói trágico" (Rocha Pereira, ibid., p. 26). Por isso, convém esclarecer, "hamartia náo é culpa, nem dor, nem erro, mas incapacidade de atingir o alvo, incapacidade do Homem de coincidir com os seus próprios fins, o que o transformaria de mortal em deus; hamartia é a própria limitação constitucional do Homem - finitude — que pode englobar culpa, dor ou erro (ou ser actualizada numa dessas várias formas) mas que as ultrapassa para significar um dos aspetos da própria condição humana" (Fialho, 1977, p. 384).

7 Não obstante, Klimis lembra que Aristóteles nâo pretende fazer resultar o prazer estético de uma simpatia (sympathein) nem de uma empatia, papel que cabe à música, mas de um reconhecimento, porque a tragédia, ao invés da música, está submetida a um desvio pela synthesis ton pragmaton, que necessita de um esforço de raciocínio por parte dos espectadores, a fim de que estes sejam afetados pelas emoçóes mediatizadas pela reflexão (vide Klimis, 1997, p. 123). 
prazer inerente à compaixão e ao temor, é evidente que isso deve ser gerado pelos acontecimentos (1453b 1014) ${ }^{8}$.

E também este prazer peculiar ou próprio da tragédia possui uma dimensão fortemente ética, como veremos seguidamente. Imitar (mimeisthai), diz Aristóteles (2004, 1448b 5), é inato (symphyton) e instintivo no homem, sendo uma atividade da qual extrai prazer. O mesmo aponta as duas causas naturais (physikai) que geraram a poesia: a aprendizagem e o prazer cognitivo ou intelectual. Imitar é algo conatural ao homem desde a infância e isto diferencia-o dos restantes animais, pois o ser humano adquire os seus primeiros conhecimentos imitando, acrescenta o mesmo $(2004,1448 \mathrm{~b} 78)$. A segunda causa prende-se com o facto de todos os homens se comprazerem com as imitaçóes, pois até as coisas mais repugnantes, se forem bem imitadas, geram prazer no espectador (2004, 1448b 8).

O artista, ao representar os universais ou as formas, representa a realidade verdadeira ou necessária e provável ou verosímil; ao imitar essa realidade, sente em si e desperta naqueles que apreciam a obra um prazer intelectual que é aduzido do facto de a compararem com o objeto representado. Acontece que, se alguém não viu previamente o modelo original, obviamente, não o pode reconhecer e, nesse caso, a obra de arte não produz de forma eficiente, através da imitação, o prazer (hedonê) genérico, característico de toda a poiesis. Todavia, esse prazer pode ser apenas estético e ter outras fontes: a execução talentosa, a cor, o ritmo, a harmonia, a proporção do representado ou alguma outra causa desse género. No caso da obra poética em verso, por exemplo, a harmonia e a repetiçáo conatural ao ritmo (pois o ritmo é recorrência ordenada) suscita em nós, naturalmente, prazer, pelo facto de estes elementos rítmicos e harmónicos serem percebidos com o nosso sentido inato de ritmo e harmonia. Este deleite, que qualificamos de estético, é também intelectual pelo facto de nos regozijarmos ao integrar os esquemas repetitivos num todo já reconhecido e percebido noutras representaçóes miméticas e na própria natureza. Podemos perceber a repetição em que consiste o ritmo, por exemplo, também nos movimentos da coreografia, na disposição das cores na pintura e nas sequências harmoniosas da música.

A mimesis implica sempre a phronesis, ou seja, a inteligência da ação, que se traduz em aprendizagem, dedução e reconhecimento?.

A razão disto é também que aprender não é só agradável para os filósofos mas é o igualmente para os outros homens [...]. É que eles, quando vêem as

\footnotetext{
8 Perante este facto, Ricœur observa: "On ne saurait guère pousser plus loin l'inclusion de l'effrayant et du pitoyable dans la texture dramatique” (1983, p. 92).

9 "Apprendre, conclure, reconnaître la forme: voilà le squelette intelligible du plaisir de l'imitation (ou de la représentation)" (Ricœur, 1983, p. 83).
} 
imagens, gostam dessa imitação, pois acontece que, vendo, aprendem e deduzem o que representa cada uma, por exemplo, "este é aquele assim e assim". (Aristóteles, 2004, 1448b 12-17)

O intelectualismo estético de Aristóteles, aludido na Metafísica (980a 21) e igualmente teorizado na Retórica (1371b 4), assenta neste reconhecimento que gera prazer, porque quem contempla decifra na imagem as correspondências da imitaçáo com o modelo original, ou seja, desse modo aprende e se regozija (vide Eire, 2002b, pp.115-116, nota n. ${ }^{\circ} 11$ ). A aprendizagem gera prazer e o prazer adveniente do reconhecimento gera aprendizagem. Aristóteles estabelece assim um elo entre a mimesis entendida com reminiscência e a mimesis estética.

O prazer estético resulta, então, do relacionamento que o filósofo grego estabelece entre a representação mental que é a memória e a representação estética produzida pela mimesis. Mas, sendo esta representação estilizada e não apenas um duplicado, para que haja reconhecimento, é preciso haver uma estância mental que serve de intermediária, visto que há um desvio entre o representado e o representante. Assim, para que o espectador reconheça na imagem o seu modelo implícito, precisa de fazer um raciocínio silogístico que lhe permita associar os dois termos. Este reconhecimento só é possível porque o observador cria na sua mente uma representação da coisa representada. Aristóteles releva aqui, implicitamente, o papel fulcral da imaginação do espectador como móbil do reconhecimento e do prazer daí adveniente.

Ademais, o texto diz que este prazer aparece acompanhado com a aquisição de um certo saber prático que concorre para a aprendizagem quer da criança quer do adulto, "car c'est par la dissemblance que l'homme peut apprendre quelque chose sur son semblable" (Klimis, 1997, p. 117). As crianças aprendem a reconhecer a sua humanidade através de jogos, que são também uma espécie de representação; os adultos, vendo representados no mundo da ficção personagens em vez de homens reais, reconhecem as suas próprias paixóes e vícios, podendo esse reconhecimento, depois de uma introspeção, movê-los a uma autocorrecção. Apercebemo-nos, assim, da extrema importância que assume este corte da mimese em relaçáo ao mundo real, atestando a necessidade do confronto com o outro para melhor se compreender a si próprio.

A acrescentar ainda aos dois prazeres genéricos acima referidos há ainda o que Eire designa de prazer ético-psicológico, referindo-se àquele que é derivado da katharsis, e que Aristóteles define como o "prazer próprio" do mythos trágico. Este é ético ou político porque move os espectadores a agirem de acordo com o bem comum da polis, transformando-os em melhores cidadãos; é psicológico ou emotivo porque, através da purificação das paixôes de temor e compaixão dos caracteres, afeta as emoçóes do auditório, provocando-lhes, paradoxalmente, um prazer também ele catártico (vide Eire, 2002, pp. 98-100).

Sintetizando, podemos dizer que o prazer ou efeito derivado da composição trágica tem três raízes, todas elas de cariz cognitivo ou intelectual: o efeito genérico 
comporta o prazer intelectual, resultante da comparação de uma representação com o seu modelo, e o prazer estético, proveniente do gozo que a perfeição artística provoca nos espectadores; o "efeito próprio" do género trágico é o prazer ético-psicológico, fruto da purgação ou da katharsis. Os três estão interligados e podem ser integrados na categoria maior e unificadora da phronesis, já que todos dependem da operação intelectual de conhecimento, dedução e reconhecimento. A finalidade de toda a obra poética é, pois, hedonista, uma vez que consiste, no caso da tragédia, na produção de um efeito catártico no público. Esta finalidade determina a forma substancial da tragédia, a sua estrutura e o seu conteúdo, que devem estar orientados para suscitar no espectador sentimentos de terror e de compaixáo.

\section{A Praxis entre Ética e Poética}

Dadas as consideraçóes anteriores, podemos concluir que a praxis, enquanto objeto da mimesis, pertence simultaneamente ao domínio do real, a cargo da ética, e ao domínio da ficçáo, a cargo da poética. Nesse sentido, a mimesis opera não somente um corte que cria a liberdade de ficção, mas também uma ligação entre estes dois mundos, que lhe permite estabelecer o que Ricoeur designa de "statut de la transposition "métaphorique" du champ pratique par le mythos" (Ricoeur, 1983, p. 93). É o agir e o sofrer humanos que a poética transpóe para o poema como sublinha ainda o filósofo francês (Ricoeur, 1983, p. 94).

Se a mimesis, que tem como objeto a ação humana, estabelece uma ponte entre o mundo prático da ética e o mundo ficcional da poética, é imperativo preservar no próprio conceito de mimese uma referência ao que precede a composição poética, referência esta à qual Ricoeur chamará mimese I, distinguindo-a da mimese II, que corresponde à criação literária, às quais há ainda a acrescentar a mimese III, ou seja, a que o filósofo francês considera a propósito da receção do mythos pelo espectador ou pelo leitor. É que, segundo ele, a mimese criativa tira a sua inteligibilidade da sua função de mediação, que vai do ponto de partida do texto até ao ponto de chegada do mesmo, através do seu poder de configuração poética ${ }^{10}$. Contudo, neste contexto, interessa fixarmo-nos para já na referência a montante da criação poética ou ponto de partida do texto, equivalente ao mundo da praxis ética, objeto da mimesis. Para tal, importa colher algumas mençóes esparsas na Poética aristotélica.

Aristóteles teoriza o modelo trágico, constituindo-se a partir da imitação desta precompreensão que antecede o labor literário. O mythos trágico é uma

10 «J'espère montrer qu'elle [l'activité mimétique] tire son intelligibilité de sa fonction de médiation, qui est de conduire de l'amont du texte à l'aval du texte par son pouvoir de refiguration» (Ricoeur, 1983, p. 94). 
exploração das vias pelas quais a ação lança, inesperadamente, os homens virtuosos na desgraça. Para isso, urde-se com as peripécias que privam o ser humano da felicidade e o mergulham no infortúnio. Neste ponto, a tragédia representa um contraponto à ética aristotélica, que ensina como é que a ação humana, através do exercício das virtudes, consegue deixar a infelicidade e alcançar a felicidade.

Do mundo da ética, o filósofo grego retira os dois conceitos fundamentais que suportam a ponte entre ética e poética através da mimese: praxis (ação) e êthos (carácter). É de assinalar que a Ética trata a felicidade apenas de forma potencial, isto é, considera as suas condiçóes gerais, ou seja, as virtudes para se alcançar a felicidade, mas não considera as circunstâncias particulares para tal. Por isso, afirma Ricoeur (1983, p. 95), o laço entre as virtudes e as circunstâncias da felicidade é aleatório. Já a poética, em virtude das intrigas construídas pelo poeta, confere inteligibilidade a este laço contingente, dito de outro modo, a poética, construindo um enredo, confere inteligibilidade, sob uma espécie de ilustração, aos preceitos demasiado abstratos da ética. Recapitulemos: em primeiro lugar, as personagens que o poeta representa são "agentes" (prattontas) — pessoas que agem (1448a 1); relativamente ao carácter, já dissemos que essas personagens representam pessoas de alta ou baixa estirpe, pessoas nobres ou más, categorias com as quais o autor discrimina toda a humanidade (pantes), consoante o género literário seja, respetivamente, tragédia ou comédia, já que uma imita indivíduos melhores que os atuais, e a outra imita-os piores; ou seja, como vimos anteriormente, os caracteres são quem permite qualificar as personagens em ação.

Há que reter daqui duas ideias fundamentais: o objeto da representação é o homem segundo a ética; e, portanto, as qualificaçôes éticas do mythos advêm do mundo real. Corroboram-no expressóes como "toda a humanidade" (1448a 4) e "quer representar indivíduos melhores (beltious) ou piores (keirous) que os actuais (ton nun)" (1448a 16-18).

A atividade mimética é, então, não apenas rutura, mas também elo, pois realiza aquilo que Ricoeur designa de "deslocamento mimético" ou "transposiçáo" quase metafórica ${ }^{11}$ do mundo da praxis para o mundo da poética, isto é, da mimese I para a mimese II. O mythos instaura, realmente, um corte entre o mundo da ética e da poética, porque abre a uma nova realidade, mas a praxis, comum às duas dimensóes, é um elemento unificador, enquanto é transposta, pelos mimoumenoi, do domínio dos êthoi para o domínio da poiesis. Assim, conclui Ricoeur: “s’il n’est pas douteux que

11 «Bref, pour que l'on puisse parler de 'déplacement mimétique', de 'transposition' quasi métaphorique de l'étique à la poétique, il faut concevoir l'activité mimétique comme lien et non pas seulement comme coupure». (Ricœur, 1983, p. 96) 
le terme muthos marque la discontinuité, le mot de praxis, par sa double allégeance, assure la continuité entre les deux régimes éthique et poétique, de l'action" (1983, p. 96).

Não obstante, a presença da ética na poética não se cinge ao fundo cultural no qual o poeta encontra uma categorizaçáo implícita do campo prático; nesse fundo cultural o mesmo descobre também uma primeira construção narrativa do campo prático. Efetivamente, os poetas trágicos gregos elaboraram as suas tragédias com base em nomes e mitos que a tradiçấo helénica lhes transmitiu.

Sem mitos transmitidos entre os Gregos, nada haveria que pudesse ser poeticamente transposto, pois faltaria, v.g., a fonte inesgotável da violência recebida dos mitos pelo poeta trágico ou o denso potencial trágico da história de casas célebres. (Pereira, 1993, p.438)

Fazem parte desse tesouro inesgotável a casa dos Atridas e a casa de Édipo, entre outras, que foram uma fonte sublime de matéria violenta, transposta pelos poetas para o efeito trágico. Com o recurso a nomes de homens que a tradição conhecia, os poetas tornavam as suas tragédias mais persuasivas ou convincentes (pithana), porque como afirma Aristóteles:

o possível é fácil de acreditar. Na verdade, nós não acreditamos que coisas que ainda não aconteceram sejam possíveis; ao contrário, pelo facto de terem acontecido, torna-se evidente que eram possíveis, pois não teriam ocorrido se fossem impossíveis. (2004, 1451b 15-18)

Assim, não é de admirar que o autor aconselhe os poetas a explorar este filáo recebido da tradiçáo, dizendo que um poeta náo é pior poeta por compor as suas intrigas com base em acontecimentos reais (genomena), pois "nada impede que alguns factos que realmente aconteceram sejam possíveis e verosímeis e é nessa medida que ele é o seu poeta" (2004, 1451b 29-32).

Para rematar o esquema ricoeuriano da tríplice mimese que temos vindo a seguir, falta-nos relevar o carácter acentuadamente ético da mimesis III, a qual encontra na katharsis aristotélica um bom fundamento. De facto, um dos conceitos chave que, em Temps et récit I, Ricoeur trabalha, a partir da Poética aristotélica, é o de katharsis. Este permite ao filósofo francês fazer a desejada ponte entre a ação imanente ao drama e o mundo praxistico do espectador, que levará à fundação da referida mimesis III e contribuirá de forma decisiva para a estética da receção, um dos pilares da hermenêutica ricoeuriana ${ }^{12}$.

12 "É essa posiçấo chave da katharsis, na flexão da acçấo mimada pelo drama e do mundo práxico do espectador, que tornará possível o seu reemprego na escala de uma estética da 
A katharsis é o conceito mais controverso e um dos mais discutidos da Poética. No entanto, Aristóteles apenas se referiu à katharsis poética duas vezes, de forma breve e elíptica, na Poética e na Politica. O termo aparece inserido na definição de tragédia, não sendo alvo de qualquer reflexão: "[a tragédia] por meio da compaixão e do temor, provoca a purificação [katharsis] de tais paixóes" $(2004,1449 \mathrm{~b} 28)$. Na Politica, a katharsis surge relacionada com a música, sendo o efeito musical comparado a uma purgação corporal e a uma cura medicinal. Trata-se, portanto, de uma metáfora para explicitar a katharsis própria da música. Relativamente à katharsis trágica, encontramos uma dificuldade de interpretação na expressão, pelo facto de não sabermos se o genitivo é objetivo ou separativo (vide Rocha Pereira, 2004, 13 et passim). Será que são as paixốes do espectador que são purificadas ou as que são representadas na tragédia? A pergunta fica sem resposta. Para além disso, há a tentação de examinar conjuntamente a katharsis musical e a trágica, para daí colher informaçôes com vista a uma definição geral do conceito. Ora, esta abordagem conjunta dos dois termos pode resultar numa assimilaçáo que não tem em conta as especificidades de cada um. São estas as principais dificuldades e os perigos inerentes à tentativa de compreensão e definição do conceito. Assim se explica a diversidade de interpretaçôes, por vezes antagónicas, que este termo tem suscitado entre os comentadores da Poética ${ }^{13}$.

Ricoeur (1983) e Klimis (1997), a partir do estudo de Lallot e DupontRoc (1980), entendem a catarse como uma purificação ou depuração que tem no espectador a sua meta e que consiste em fazer derivar do temor e da compaixão o "prazer próprio" da tragédia, que é não um sentimento de pena, mas de prazer. A katharsis transforma em prazer estético a dor inerente a estas emoçóes, substituindo a pena pelo prazer. Nunca é de mais lembrar que esta reação subjetiva é, em primeiro lugar, produzida ao nível intratextual, sendo construída no e pelo mythos. A primeira depuração reside na própria construção poética, visto que a representação poética das emoçôes resulta

\footnotetext{
recepção. Assim, o terceiro termo de nosso ternário revela ser, paradoxalmente, ao mesmo tempo o mais dependente das obrigaçôes limitativas do género trágico (as paixões purificadas continuam sendo a piedade e o terror) e o mais aberto para uma retomada, na qual a aisthesis desdobraria a capacidade de aplicação da katharsis muito além das duas paixôes trágicas" (Ricoeur, 1992, p. 334).

13 Sobre as principais tendências interpretativas do termo ao longo dos tempos, vide Klimis (1997, pp. 132-150). Relativamente às diferenças entre a catarse musical e a trágica, a mesma autora, na página 144, esclarece que a katharsis musical age diretamente ao nível do pathos, e está muito próxima da purgaçáo física com a qual pode ser comparada. Ao contrário, a katharsis trágica toca o corpo patético do seu público por intermédio do texto, o qual implica uma operação de reflexão por parte dos espetadores. A reflexão torna-se assim a condição de possibilidade da impressão afetiva. Klimis entende, por isso, a catarse trágica como uma forma sublimada da catarse musical, porque consegue tocar o pathos do público recorrendo exclusivamente ao encadeamento discursivo, sem precisar de uma figuração corporal.
} 
da própria composição ${ }^{14}$. Note-se, todavia, que a depuração intratextual não é a dos caracteres, mas a da ação, identificável com a sunthesis tôn pragmatôn. O esqueleto da ação deve reunir as condiçóes necessárias para transformar a compaixão e o temor do espectador em prazer. A dialética interior/exterior atinge, então, o seu clímax na catarse, enquanto é sentida pelo espectador e está implicada no próprio drama. Nesse caso, podemos falar de um duplo processo de catarse: uma catarse interna ao texto que é condição de possibilidade de uma segunda catarse externa ao texto, porque implica as emoçóes dos espectadores. Para Klimis (1997, p. 141), esta passagem da katharsis intratextual à extratextual acontece por intermédio da reflexão do público, ou seja, por meio da interpretação. O espectador só pode participar na catarse imanente ao texto através de um processo exegético, que o leva a assimilar e a fruir um prazer estético possibilitado pela estrutura textual.

Relativamente à tese de Ricoeur, podemos sintetizar dizendo que consiste em fazer derivar da aprendizagem, bem como do temor e da compaixão, o prazer próprio da tragédia que se faz sentir nos espectadores. Mas este cruzamento da ética com a poética é criticado por Sophie Klimis, que sustenta uma visão discordante. Discorda da interpretação ricoeuriana, argumentando que a relação entre a ação trágica, interna ao mythos, e a ação ética, pertencente ao domínio do extralinguístico, não tem justificação, por se tratar de duas ações que visam fins diferentes. A ação ética é uma ação particular que visa somente a felicidade (eudaimonia) daquele que age até ao fim da sua vida, em função do seu carácter (ethos). Esta ação está subordinada aos critérios éticos da virtude (arethe) e da prudência (phronesis). A ação trágica, que pertence ao domínio da ficção, tem como único e soberano objetivo suscitar a compaixáo e o temor no público, representando um esquema de ação universal, onde o efeito da praxis não tem importância para o agente, neste caso a personagem, mas apenas para o público. Esta ação obedece às condiçôes gerais do êthos e do pensamento discursivo, dianoia, e acerca desta estrutura Aristóteles não especula nenhum sentido ético, já que o seu fim único ou prazer próprio é suscitar no público emoçóes de temor e compaixão. Por conseguinte, perora Klimis (1997, p. 69): “on voit donc que l'action tragique n'est pas superposable à l'action éthique”. Ademais, a autora diz reconhecer a falha de Ricoeur no facto de o filósofo náo considerar como objetivo único da ação trágica o de tocar o pathos do público, limitando-se exclusivamente ao prazer intelectual proveniente do reconhecimento dos modelos éticos no mythos trágico.

${ }^{14}$ A propósito, Baptista Pereira comenta que "a katharsis não é menos fictícia que a mimesis e o mythos, pois é a compreensão sentida da fábula, que purifica as paixões” (1993, p. 430). 
Esta crítica parece-nos injustificada, na medida em que o próprio Ricoeur acautela os dois objetivos da intriga trágica: a katharsis, da qual advém o prazer ético-psicológico; e o reconhecimento, do qual advém o prazer intelectual; e estes dois efeitos, acrescentamos nós, não se podem isolar, porque se interpenetram e formam em conjunto a estética de uma obra. Em segundo lugar, se a mimesis é mimesis praxeos, a ação representada só pode ser do mundo extralinguístico, caso contrário não haveria mimese, mas simples criação ex nihilo. Ainda que as duas açóes possam ser distinguidas pelos fins próprios diferentes que pretendem atingir - na verdade, uma visa conduzir o agente da infelicidade à felicidade e a outra da ventura à desventura - não podemos obliterar o facto de nos dois domínios da ética e da poética existirem indivíduos que agem e de todas as açôes humanas possuírem qualidade ética. Todo o agir tem determinaçáo ética ou política; logo, tal como não pode haver ação sem êthos, também não pode haver êthos sem ética. Percebe-se, pois, Ricoeur quando refere que o êthos e a praxis são os denominadores comuns da ética e da poética, apesar de tal náo significar que tenham o mesmo tratamento no campo da realidade $\mathrm{e}$ da ficção, em função, precisamente, dos objetivos que pretendem atingir. Partilhamos, neste âmbito, a leitura de Portocarrero:

A katharsis funciona como efeito da obra, uma purgação (poética) de paixôes, isto é, como uma transfiguração do ético pelo poético ou, ainda, em linguagem ricoeuriana, como um alargamento dos quadros éticos e simbólicos do nosso horizonte de compreensão da praxis (nos seus valores fundamentais). A praxis em Aristóteles, não o esqueçamos, pertence simultaneamente ao domínio ético e ao âmbito poético. Daí que o mythos se situe na charneira do teórico e do prático e nos interpele: ele gera tramas e figuras, que enriquecem a nossa condiçáo temporal de agentes, pela possibilidade de identificaçáo que oferecem. (Portocarrero, 2005, p. 65)

Além do mais, é-nos difícil aceitar que a única intenção das tragédias clássicas seja essencialmente emocional e lúdica, quando sabemos que inerente à arte grega clássica estavam sempre axiomas éticos e políticos. Ver em Édipo apenas um provocador de pathos parece-nos redutor. Será que podemos olhar para estes heróis trágicos sem reconhecer neles modelos universais e intemporais? Acreditamos que não.

Nesse sentido, a mimesis III de Ricoeur ainda vai muito mais além, focando "o mundo" que a obra literária desenrola diante do leitor e do qual este se apropria. É verdade que Aristóteles náo adiantou muito neste campo, mas - aos olhos do filósofo francês - legou-nos o espectador ideal, e ainda melhor, o leitor ideal: "son intelligence, ses émotions “épurées", son plaisir, à la jonction de l'oeuvre et de la culture que celle-ci crée» (Ricoeur, 1983, p. 104). 


\section{Bibliografia}

Aristóteles (1980). La Poétique (trad., notes de R. Dupont-Roc \& J. Lallot). Paris: Seuil.

Aristóteles (2001). Ética a Nicomaco. Madrid: Alianza Editorial.

Aristóteles (2002). Poética (prólogo, trad. y notas de A. L.Eire) Madrid: Istmo.

Aristóteles (2004). Poética. Lisboa: Fundação Calouste Gulbenkian.

Aristotle (1968). Poetics (Lucas, D. W.). Oxford: Clarendon Press.

Eire, A. L. (2002a). Poéticas y Retóricas griegas. Madrid: Editorial Síntesis.

Fialho, M. C. (1977). Algumas consideraçôes sobre o homem trágico. Biblos 53, 375-388.

Klimis, S. (1997). Le statut du mythe dans la Poétique d'Aristote. Bruxelles: Ousia.

Pereira, M. B. (1993). Narração e Transcendência. Humanitas, 45, 393-476.

Portocarrero, M. L. (2005). Horizontes da Hermenêtica em Paul Ricoeur. Coimbra: Ariadne.

Rocha Pereira, M. H. (2004). Prefácio. In Aristóteles, Poética. Lisboa: Fundação Calouste Gulbenkian.

Ricœur, P. (1983). Temps et récit I: l'intrigue et le récit historique. Paris: Seuil.

Ricoeur, P. (1992). Lectures 2. Paris: Seuil. 